\title{
EFFICIENCY AND ASSESSMENT OF SOCIAL TECHNOLOGY
}

\author{
Venelin Terziev \\ Academician of the Russian Academy of Natural History, Moscow, Russia, Prof. D.Sc. (Ec.), D.Sc. \\ (National Security), D.Sc. (Social Activities), Ph.D., National Military University, Veliko Tarnovo, \\ Bulgaria; University of Rousse, Rousse, Bulgaria, terziev@skmat.com
}

\begin{abstract}
The paper examines some of the most important criteria and indicators for social efficiency. Fundamental ideas of the Bulgarian and foreign economic science for the specifics of social efficiency in the activity of the subjects of institutional governance, including the bodies of state power are discussed. The paper applies a comprehensive (interdisciplinary) approach suggesting integration of sociological, theoretical and management, socio-economic and other aspects of the study is related to the system analysis. The social governance is seen from the perspective of a system method, being the regulation of the relations between the subject and object of management as a purposeful impact on the social system in order to bring its operation and development in accordance with socially significant goals.
\end{abstract}

Keywords: social policy, social program, social efficiency.

\section{INTRODUCTION}

Theory of organization and administration defines the efficient management as an attitude of pure positive results (exceeding desired consequences over undesired) and the eligible costs. The decision may be called effective if the best result is achieved in the given temporary expenditure or if the result is obtained at the lowest cost for the choice.

Modern societies are experiencing a crisis of efficiency of traditional systems for state government. We can analyze three key factors that influence the formation of the crisis: socio-political, economic and sociocultural. Overcoming the crisis by modern democracies and thus solving the problem of the efficiency of administrative government is directly related to the establishment of a management paradigm corresponding to the maximum extent of the new cultural, social and political situation. As a management paradigm, it is suggested to consider the synergistic methodology. It is believed that the concordance theory denied extremes of deterministic and atomistic positions on the analysis of institutional systems, providing to researchers two key categories for the conceptualization of the term «social efficiency»: «interpretative rationality» and "transaction costs». These categories contribute to the decision of the main research task: the search for a general principle, proceeding from which to interpret the term «management decision» in the context of different institutional subsystems, recognizing that each of them has its own specific set of goals. 
Besides the "economic» component of the concept of efficiency (the ratio between the volume, provided services to the value or volume of resources needed to provide the volume of services), we can note also the «technical» or organizational part, determined by the positions of reaching goals. The technical efficiency indicates the extent of compliance of the state services with the needs, desires and resources of their clients.

\section{EFFICIENCY OF SOCIAL TECHNOLOGY}

The concept of social efficiency is considered in the context of the new paradigm of state government. The Western researchers (M. Dimok, Anicet Le Port, J. Lane etc.) in the definition of the concept of social efficiency, address the question of resource allocation as methodologically closer to the political economy or the management of the organizations. Social efficiency is determined as a function of minimization of transaction costs (costs of exchange). Accordingly, a basic condition for socially efficient management is the presence of an effective mechanism for coordination of the social interactions. Transaction costs which are most typical for the government system can be of the following types: costs of opportunistic behavior («truancy», «influence», «agency costs», «blackmail» politicization costs, etc.)

Within the conditions of a transitional period, we may talk about a systemwide crisis, covering all spheres of society for a long period of time. The success of the economic reforms depends on two sets of conditions: considering the interests of the subjects of reforms (mostly the political elite of the country) and recognizing the need for reform objects (management and staff of enterprises together with all forms of property, the regional structures, broad strata population). Moreover, the reporting of interests shall be carried out on «accounting» level and through the study of more specific motivations covering the multilayer structure of needs.

The experience in industrial and postindustrial development of all countries in the world without exception demonstrates the inadequacy of the purely technocratic approach to management. New technologies, information, taylorism, economic-mathematical methods are very important, but they allow reaching real efficiency and competitiveness only through the social motivation of workers and establishment of a system of a well thought stimulation system. It brings out criteria for assessing the social performance of the system of government. Two groups are differentiated with such criteria: general systems, which include balance, stability, diversity, presence of feedback, etc. and specifically social, as the most important of which should be considered the provision of social security and social protection of the population.

The problem of social efficiency is closely intertwined with the issue of the security of the social system. Statistically, under safety of the social safety we can understand a specific region of a territory, the condition of this system, the parameters of which are determined by the historically conditioned public ideal. For the contemporary Bulgarian society in particular, going abroad and being outside the borders of the defined territory means getting closer of the society to a variety of totalitarian regime.

Very important for this study are the developments, which reveal the problem of efficiency of the different social events or technologies.

Social technology is a method of management of social processes, which secures the system through consistent actions of the individual, the team, the management bodies of the region, district, municipality, settlement. The model of «Technologicalization» or technological development of social space (layout) through the presented by it social objects and processes, set of signs, properties, characteristics, nature of formation, manifestation and reproduction. It is more appropriate to evaluate technologies in terms of optimality of the way for achieving the set target and ensuring the achievement of certain results.

Efficiency of social technologies can be assessed based on recently received widespread assessment studies. Assessment studies can be conducted by both the developer and the guarantor of a social technology. It is important to emphasize that it can be carried out at the stage of development, and at the stage of implementation of the technology.

The practice of assessment study can be oriented not to the entire technology, but to a separate part of it. It should be noted that in an assessment study of the process there is orientation to the internal characteristics of the technology, allowing judging its positive and negative qualities.

In this case, the productive and implementation strategies of research orientation pass in search and assessment of external effects or its productivity.

Assessment of the efficiency of technology can be made based on different models. The target model for assessment studies is aimed at evaluation of the targets, the compliance of social technology of the set in its objectives and determination of the extent of their implementation. Firstly, in this case the quality of reporting and the list of potential targets is assessed, which may be related to the specific social technology. The basis 
of such an assessment can be made through analytical and expert methods. Secondly, the technological procedures are assessed in terms of their relevance to the lofty goals. The efficiency of technology is higher if it corresponds to its designated objectives.

The untargeted assessment study is aimed at detecting overt or latent effects of the social technology. The assessment of the efficiency of the social technology relates to the complexity of the set of expected effects: on the one hand, there is polymodality of the real effects of the object, subject and the social technology itself as a means, and the other there is no adequate valid document for their measuring.

Efficiency of social technologies can be measured by comparing the possible levels of action: the first gives evidence that it can be achieved with the existing resources and restrictions without technology deployment, and the second is related to the deployment of specific technologies at existing resources and limitations and potentially in the development of the technological resources and the removal of restrictions of various kinds. In addition, we can talk about the limits of growth of efficiency of social technology in the presence of resource constraints for its implementation.

Efficiency of social technology is determined by subjective and objective factors. To the number of the first we should refer the individual characteristics of the people, involved in the realization of a particular technology, the level of their professional training and status. To the objective factors, we can refer the factors for business organization: the objective conditions of the environment, the workplace, the flow of information, control over the activity.

There are a number of attempts to characterize the efficiency assessment of social events (social projects and programs). Moreover, under the social event, the specific activity of this or that organization is understood, in order to amend the social status of a social group or category of people in the desirable direction. A private social event is usually expressed in the creation of legal, technical and economic conditions for the realization of every set goal. The complex of social events, united by common goals, is called social program.

\section{ASSESSMENT OF SOCIAL EFFICIENCY}

A common model for assessing the efficiency is the next scheme resource provision for the activity: expenditure - result. A characteristic feature of this scheme appears to be separation of the role of resource provision and the costs for increase of the efficiency of the management activity.

The model for effective organization of R. Laykert identifies three factors:

- The factors for internal organization - formal structure of the organization, economic structure and social policy, professional qualification of employees;

- Impermanent variables - human resources, organizational climate, decision-making methods, level of trust towards the management, methods of stimulation and motivation for activity;

- Effective variables - growth or decrease of labor productivity and income, level of satisfying consumer demand and more.

With this approach, the efficiency is born as a result of a complex interaction between various factors, among which a dominant position is occupied by the human, social and environmental factors.

Another approach where efficiency is measured at the level of protection of the balanced interests of the state and society is also worth attention. The work of the state apparatus may be recognized as effective only in case if it successfully solves the problem for optimal protection of the interests of the population, social groups and every person. In this dual task, the most important part is the concept of efficiency of the state apparatus. According to this approach, its efficiency is expressed in expanding the opportunities for active civic life of every citizen, the society and the efficiency of the state. It provides a well-functioning system for the state authorities, their ability to legally implement state interests and implement state policy on social and community development.

Another point of view that connects the efficiency of governmental activities is the presence or absence of optimal paradigm for administrative and political management. It comes to opposing the traditional technocratic paradigm of political government to the new participative one.

Overall, the authors directly link the efficiency of the governmental activities with the presence in it of bureaucracy that is actually serving society. This bureaucracy:

- is under the real control of society; 
- Expresses the interests of social progress; - is minimal in its quantitative and qualitative parameters.

This statement is based on an inherent contradiction in the bureaucracy between broad public purposes for which it has been created and its close corporate interests with the tendency to dominate.

According to some authors, efficiency criteria of social management consist of the following:

The compliance of the directions and the content and performance of the management structures and of these parameters, which are determined by the functions and status;

- The legality of the decisions and actions corresponding to the management structures and the users (beneficiaries);

- The reality of the impact of the management on the status and development of the managed sites;

- The depth of reporting and presentation in management decisions and actions on specific and complex needs, interests and goals of the people;

- The nature and volume of the direct and reverse connections with labor groups, wide range of people, or in other words in the democracy of the activities;

- The extent of authority of the decisions and actions of the management structures;

- The credibility and relevance of the information transmitted to the management structures and beneficiaries;

- Impact of the management activity in relation to the external environment.

Any action, any social event or quality (including social efficiency) is characterized by quantitative and qualitative aspects. Even though these two aspects of the object exist in an inseparable unity and interconnection, they are still different characteristics of the surrounding social reality. The scientific literature has adopted the term "criterion» to indicate the qualitative aspect of the result (effect) and the term «efficiency indicator» to denote the quantitative aspect.

Other research suggests a slightly different interpretation of the term "criterion of social efficiency», considering it in terms of the relationship between the qualitative and quantitative determination of the studied and assessed object. In respect to the quantitative aspect, the criterion appears as a method, an instrument, a reference measure for moving towards the desired outcome, and in respect to the quantitative aspect - as an opportunity to separate the "positive aspects, forms of this movement in space and time».

However, in all of the differences in the understanding of the term «criterion» in the designated approaches there is a meaningful unity, except that their synthesis gives us new, deeper understanding of the social nature of the social efficiency.

Thus, the indicator of efficiency (quantitative criterion) fixes the objective and integral - mainly quantitatively expressed (e.g. in terms of the natural volume of social benefits and the time interval to secure them) assessment of the achievements of the social system of every rank, and the efficiency criterion (quality criterion) to a greater extent is focused on the study of the internal mechanisms for achieving a specific result, including the degree of limitation, etc. - activation of the human factor as a condition for selfdevelopment, efficient operation, social cost of achievement or the extent of its limitations, etc.

This distinction is essential and important for the development of the system for the assessment of social work.

No matter what is the quantity of efficiency of the operating and the developing social system, it is always a result of the actions of all the factors of the system as a whole, presented as an integrative productivity of research. It is important to emphasize that even if the activity of the separate factors in the social system is extraordinary efficient, its efficiency can be secured only by the corresponding quality of systematic social interaction that comes as its irrevocable organic property and serves as a general algorithm and universal motivational mechanism for the activities of all the factors in the system.

The relationship between economic and social efficiency has a complex character. At the basis of the growth of economic efficiency, the following methodological principle is usually placed: the implementation of the social program is in itself bound to become a catalyst for effective economic development.

The funds spent by society to meet social needs, in the end are returned as evident increase of the social and labor efficiency. In this system, the realization of social control is ultimately one of the subordinate factors for achieving economic efficiency. 
The effort to treat in a similar way the impact of the economic factor for achieving integrated social performance, will inevitably suffer from a simplistic approach. It has already been recognized as obvious that at a certain essence of the social efficiency, the classic criterion (the ratio between cost and income) is clearly insufficient. We need a different approach, by means of which to assess the effectiveness of one or other social events. The level for achieving social efficiency, which is determined by the position of the movement to a socially significant ideal that is comprehensively revealed as a state of the most complete realization of human needs and self-realization of their essential strengths, in other words their personality. The prosperity of the person as the supreme value to society becomes an end in itself for social development. Hence, the prospective objective of any development usually comes as a requirement to ensure the complete prosperity and free all-round development of all members of society, which is realized primarily in the creation of humane living and working conditions.

It is also necessary to make a number of important methodological and logical specifications. The notion of social efficiency as productivity, evaluated from the perspective of approaching the public ideal, must be related to the changes corresponding to the general line of the progressive development of the social system, i.e. with its gradual transition from the less to the more perfect existence.

We can note that before we compare any achieved social result with the costs, it is necessary to clarify the significance of the mere fact of reaching this result, especially in terms of its compliance with the objectives of social development. It is also important to take into account the time interval required to achieve the goal.

The importance of this observation for understanding the basic principle of social effectiveness and its criteria specifically emphasizes the concrete experience of social policy. The American scientist D. Rotblat stresses out that in the USA in 30s a fundamental rethinking of the principle of effective social policy has happened. Government measures on extending unemployment insurance funds and increase of the number of recipients of social tools that were initially considered as fully progressive, in the long run increasingly manifested their inefficiency as they had little impact on improving the human resource. Experience has shown that «the provision of prosperity without offering viable alternatives» for the development of the person and their initiative has become an obstacle for social progress, as long as it brings «reproduction of the culture of poverty from generation to generation». It is obvious that to the same extent that the time span allows more precisely to reveal the main line of social progress, the assessment of social activity of the carried out measures could be radically altered. According to the author, the inclusion of citizens in need of social support in the labor process, bearing perspectives in economic and social terms is more effective, than giving tools designed for short-term smoothing social tensions in society. Staging the problem of social efficiency depending on the notions of social progress and its ideal creates additional difficulties. In those cases where the social impact is difficult to quantify, the only reliable criterion for its evaluation can only be the degree of approaching the purpose - the realization of these values, which are set out in it (Terziev, Georgiev, 2018 a-h, Terziev, Banabakova, Georgiev, 2018i-t, Terziev, 2018u-y).

\section{CONCLUSION}

The problem of studying the efficiency is one of the key areas of various activities of society, especially in production and management. Traditionally, the focus is on economic efficiency, reduced to simple enough and calculated «costresult» ratio. This is a fundamental principle, characterizing the concept of «economic efficiency». Social efficiency does not have so direct character. It is rather a more complex category and is difficult to express in one dimension. Certain contradictions and discrepancies may arise between different approaches and the task for reaching the aggregate social efficiency shall be formulated primarily as a task for optimization of the social managerial activity.

\section{REFERENCE LIST}

Terziev, V., Georgiev, M. (2018a). A strategic framework for the development of social entrepreneurship in Bulgaria. // Knowledge - International Journal, August 2018, Institute of Knowledge Management, Skopje, Macedonia, 25, 2018, N1, pp. 23-34, ISSN 1857-923X (for e-version), ISSN 2545 - 4439 (for printed version).

Terziev, V., Georgiev, M. (2018b). Support for the development of social entrepreneurship in Bulgaria. // Knowledge - International Journal, September 2018, Institute of Knowledge Management, Skopje, Macedonia, 26, 2018, N1, pp.57-74, ISSN 1857-923X (for e-version), ISSN 2545 - 4439 (for printed 
version).

Terziev, V., Georgiev, M. (2018c). Sotsialna zashtita na uyazvimite grupi ot naselenieto v Balgariya. // Sbornik dokladi ot Godishna universitetska nauchna konferentsiya 14-15 yuni 2018g., Nauchno napravlenie „Sotsialni, stopanski i pravni nauki”, NVU Veliko Tarnovo, Veliko Tarnovo, Izdatelski kompleks na NVU „Vasil Levski”, 7, 2018, str. 188-193, ISBN 978-619-7246-20-9 (online e-book), ISSN 1314-1937. (Терзиев, В., Георгиев, М. Социална защита на уязвимите групи от населението в България. // Сборник доклади от Годишна университетска научна конференция 14-15 юни 2018г., Научно направление „Социални, стопански и правни науки”, НВУ Велико Търново, Велико Търново, Издателски комплекс на НВУ „Васил Левски”, 7, 2018, стр. 188-193, ISBN 978-619-7246-20-9 (online e-book), ISSN 1314-1937).

Terziev, V., Georgiev, M. (2018d). Podhodi pri obuchenie v organizatsiyata. // Sbornik dokladi ot godishna universitetska nauchna konferentsiya 14-15 yuni 2018 g., Elektronno izdanie, NVU Vasil LevskiVeliko Tarnovo, Veliko Tarnovo, 2018, str. 951-958, ISBN 978-619-7246-20-9 (online e-book), ISSN 2367-7481 (Терзиев, В., Георгиев, М. Подходи при обучение в организацията. // Сборник доклади от годишна университетска научна конференция 14-15 юни 2018 г., Електронно издание, НВУ Васил Левски- Велико Търново, Велико Търново, 2018, стр. 951-958, ISBN 978619-7246-20-9 (online e-book), ISSN 2367-7481).

Terziev, V., Georgiev, M. (2018e). Harakteristiki na sistemata za sotsialno podpomagane. // Sbornik dokladi ot godishna universitetska nauchna konferentsiya 14-15 yuni 2018 g., Elektronno izdanie, NVU Vasil Levski- Veliko Tarnovo, Veliko Tarnovo, 2018, str. 959-969, ISBN 978-619-7246-20-9 (online e-book), ISSN 2367-7481 (Терзиев, В., Георгиев, М. Характеристики на системата за социално подпомагане. // Сборник доклади от годишна университетска научна конференция 14-15 юни 2018 г., Електронно издание, НВУ Васил Левски- Велико Търново, Велико Търново, 2018, стр. 959-969, ISBN 978-619-7246-20-9 (online e-book), ISSN 2367-7481).

Terziev, V., Georgiev, M. (2018f). Sotsialna zashtita na uyazvimite grupi ot naselenieto v Balgariya. // Sbornik dokladi ot godishna universitetska nauchna konferentsiya 14-15 yuni 2018 g., Elektronno izdanie, NVU Vasil Levski- Veliko Tarnovo, Veliko Tarnovo, 2018, str. 970-975, ISBN 978-619-724620-9 (online e-book), ISSN 2367-7481 (Терзиев, В., Георгиев, М. Социална защита на уязвимите групи от населението в България. // Сборник доклади от годишна университетска научна конференция 14-15 юни 2018 г., Електронно издание, НВУ Васил Левски- Велико Търново, Велико Търново, 2018, стр. 970-975, ISBN 978-619-7246-20-9 (online e-book), ISSN 2367-7481).

Terziev, V., Georgiev, M. (2018g). Podhodi pri obuchenie v organizatsiyata. // Sbornik dokladi ot Godishna universitetska nauchna konferentsiya 14-15 yuni 2018g., Nauchno napravlenie „Sotsialni, stopanski i pravni nauki”, NVU Veliko Tarnovo, Veliko Tarnovo, Izdatelski kompleks na NVU „Vasil Levski”, 7, 2018, str. 169-176, ISBN 978-619-7246-20-9 (online e-book), ISSN 1314-1937 (Терзиев, В., Георгиев, М. Подходи при обучение в организацията. // Сборник доклади от Годишна университетска научна конференция 14-15 юни 2018г., Научно направление „Социални, стопански и правни науки", НВУ Велико Търново, Велико Търново, Издателски комплекс на НВУ „Васил Левски”, 7, 2018, стр. 169-176, ISBN 978-619-7246-20-9 (online e-book), ISSN 1314-1937).

Terziev, V., Georgiev, M. (2018h). Harakteristiki na sistemata za sotsialno podpomagane. // Sbornik dokladi ot Godishna universitetska nauchna konferentsiya 14-15 yuni 2018g., Nauchno napravlenie „Sotsialni, stopanski i pravni nauki”, NVU Veliko Tarnovo, Veliko Tarnovo, Izdatelski kompleks na NVU „Vasil Levski”, 7, 2018, str. 177-187, ISBN 978-619-7246-20-9 (online e-book), ISSN 1314-1937. (Терзиев, В., Георгиев, М. Характеристики на системата за социално подпомагане. // Сборник доклади от Годишна университетска научна конференция 14-15 юни 2018г., Научно направление „Социални, стопански и правни науки”, НВУ Велико Търново, Велико Търново, Издателски комплекс на НВУ „Васил Левски”, 7, 2018, стр. 177-187, ISBN 978-619-7246-20-9 (online e-book), ISSN 1314-1937).

Terziev, V., Banabakova, V., Georgiev, M. (2018i). Modern dimensions of social policies. // International journal scientific papers Vol 23.4 Promoted in Budva, Montenegro 24-27.05.2018, IKM - Skopje, 23, 2018, N 4, pp. 935-944, ISSN 1857-923X (for e-version) ISSN 2545- 4439 (for printed version).

Terziev, V., Banabakova, V., Georgiev, M. (2018j). Social support as part of social policy. // International journal scientific papers Vol 23.4 Promoted in Budva, Montenegro 24-27.05.2018, IKM - Skopje, 23, 2018, N 4, pp. 973-980, ISSN 1857-923X (for e-version) ISSN 2545 - 4439 (for printed version).

Terziev, V., Banabakova, V., Georgiev, M. (2018k). Structure of the social welfare system in Bulgaria. // 
International journal scientific papers Vol 23.4 Promoted in Budva, Montenegro 24-27.05.2018, IKM Skopje, 23, 2018, N 4, pp. 1275-1281, ISSN 1857-923X (for e-version) ISSN 2545 - 4439 (for printed version).

Terziev, V., Banabakova, V., Georgiev, M. (2018I). Role and place of social programing in public governance. // Mizhnarodnoï naukovo-praktichnoï konferentsiï «Zabezpechennya stalogo rozvitku ekonomiki: problemi, mozhlivosti, perspektivi» (16-17 lyutogo 2018 roku, m. Uzhgorod), Ministerstvo osviti i nauki Ukraïni Uzhgorodsykiy natsionalyniy universitet, 2018, s.93-98, ISBN 978-966-916-488-9. (Terziev, V., Banabakova, V., Georgiev, M. Role and place of social programing in public governance. // Міжнародної науково-практичної конференції «Забезпечення сталого розвитку економіки: проблеми, можливості, перспективи» (16-17 лютого 2018 року, м. Ужгород), Міністерство освіти і науки України Ужгородський національний університет, 2018, с.93-98, ISBN 978-966-916-488-9.)

Terziev, V., Banabakova, V., Georgiev, M. (2018m). Social program as a product of social programming. // Mizhnarodnoï naukovo-praktichnoï konferentsiï «Zabezpechennya stalogo rozvitku ekonomiki: problemi, mozhlivosti, perspektivi» (16-17 lyutogo 2018 roku, m. Uzhgorod), Ministerstvo osviti i nauki Ukraïni Uzhgorodsykiy natsionalyniy universitet, 2018, s. 99-104, ISBN 978-966-916-488-9. (Terziev, V., Banabakova, V., Georgiev, M. Social program as a product of social programming. // Міжнародної науково-практичної конференції «Забезпечення сталого розвитку економіки: проблеми, можливості, перспективи» (16-17 лютого 2018 року, м. Ужгород), Міністерство освіти і науки України Ужгородський національний університет, 2018, с. 99-104, ISBN 978-966-916-488-9).

Terziev, V., Banabakova, V., Georgiev, M. (2018n). Social efficiency as a measure of social activities. // Mizhnarodnoï naukovo-praktichnoï konferentsiï «Zabezpechennya stalogo rozvitku ekonomiki: problemi, mozhlivosti, perspektivi» (16-17 lyutogo 2018 roku, m. Uzhgorod), Ministerstvo osviti i nauki Ukraïni Uzhgorodsykiy natsionalyniy universitet, 2018, s. 104-109, ISBN 978-966-916-488-9. (Terziev, V., Banabakova, V., Georgiev, M. Social efficiency as a measure of social activities. // Міжнародної науково-практичної конференції «Забезпечення сталого розвитку економіки: проблеми, можливості, перспективи» (16-17 лютого 2018 року, м. Ужгород), Міністерство освіти і науки України Ужгородський національний університет, 2018, с. 104-109, ISBN 978-966-916-488-9).

Terziev, V., Banabakova, V., Georgiev, M. (20180). Assessment of the effectiveness of social programing. // Mizhnarodnoï naukovo-praktichnoï konferentsiï «Zabezpechennya stalogo rozvitku ekonomiki: problemi, mozhlivosti, perspektivi» (16-17 lyutogo 2018 roku, m. Uzhgorod), Ministerstvo osviti i nauki Ukraïni Uzhgorodsykiy natsionalyniy universitet, 2018, s. 110-115, ISBN 978-966-916-488-9. (Terziev, V., Banabakova, V., Georgiev, M. Assessment of the effectiveness of social programing. // Міжнародної науково-практичної конференції «Забезпечення сталого розвитку економіки: проблеми, можливості, перспективи» (16-17 лютого 2018 року, м. Ужгород), Міністерство освіти і науки України Ужгородський національний університет, 2018, с. 110-115, ISBN 978-966-916-4889).

Terziev, V., Banabakova, V., Georgiev, M. (2018p). Social activity of human resource as a basis of effective social policy. // Mizhnarodnoï naukovo-praktichnoï konferentsiï «Zabezpechennya stalogo rozvitku ekonomiki: problemi, mozhlivosti, perspektivi» (16-17 lyutogo 2018 roku, m. Uzhgorod), Ministerstvo osviti i nauki Ukraïni Uzhgorodsykiy natsionalyniy universitet, 2018, s. 116-121, ISBN 978-966-916488-9. (Terziev, V., Banabakova, V., Georgiev, M. Social activity of human resource as a basis of effective social policy. // Міжнародної науково-практичної конфреренції «Забезпечення сталого розвитку економіки: проблеми, можливості, перспективи» (16-17 лютого 2018 року, м. Ужгород), Міністерство освіти і науки України Ужгородський національний університет, 2018, с. 116-121, ISBN 978-966-916-488-9).

Terziev, V., Banabakova, V., Georgiev, M. (2018q). Strategic advantages of an active social program. // Mizhnarodnoï naukovo-praktichnoï konferentsiï «Zabezpechennya stalogo rozvitku ekonomiki: problemi, mozhlivosti, perspektivi» (16-17 lyutogo 2018 roku, m. Uzhgorod), Ministerstvo osviti i nauki Ukraïni Uzhgorodsykiy natsionalyniy universitet, 2018, s. 122-127, ISBN 978-966-916-488-9. (Terziev, V., Banabakova, V., Georgiev, M. Strategic advantages of an active social program. // Міжнародної науково-практичної конференції «Забезпечення сталого розвитку економіки: проблеми, можливості, перспективи» (16-17 лютого 2018 року, м. Ужгород), Міністерство освіти і науки України Ужгородський національний університет, 2018, с. 122-127, ISBN 978-966-916-488-9).

Terziev, V., Banabakova, V., Georgiev, M. (2018r). Assessment of the effectiveness of social programming. // Mizhnarodnoï naukovo-praktichnoï konferentsiï «Zabezpechennya stalogo rozvitku ekonomiki: problemi, mozhlivosti, perspektivi» (16-17 lyutogo 2018 roku, m. Uzhgorod), Ministerstvo osviti i nauki 
Ukraïni Uzhgorodsykiy natsionalyniy universitet, 2018, s. 127-131, ISBN 978-966-916-488-9. (Terziev, V., Banabakova, V., Georgiev, M. Assessment of the effectiveness of social programming. // Міжнародної науково-практичної конфреренції «Забезпечення сталого розвитку економіки: проблеми, можливості, перспективи» (16-17 лютого 2018 року, м. Ужгород), Міністерство освіти і науки України Ужгородський національний університет, 2018, с. 127-131, ISBN 978-966-916-4889).

Terziev, V., Banabakova, V., Georgiev, M. (2018s). The social program as a part of development strategies. // Mizhnarodnoï naukovo-praktichnoï konferentsiï «Zabezpechennya stalogo rozvitku ekonomiki: problemi, mozhlivosti, perspektivi» (16-17 lyutogo 2018 roku, m. Uzhgorod), Ministerstvo osviti i nauki Ukraïni Uzhgorodsykiy natsionalyniy universitet, 2018, s. 132-137, ISBN 978-966-916-488-9. (Terziev, V., Banabakova, V., Georgiev, M. The social program as a part of development strategies. // Міжнародної науково-практичної конференції «Забезпечення сталого розвитку економіки: проблеми, можливості, перспективи» (16-17 лютого 2018 року, м. Ужгород), Міністерство освіти і науки України Ужгородський національний університет, 2018, с. 132-137, ISBN 978-966-916-4889).

Terziev, V., Banabakova, V., Georgiev, M. (2018t). Social programming as a possibility to increase social efficiency. // Mizhnarodnoï naukovo-praktichnoï konferentsiï «Zabezpechennya stalogo rozvitku ekonomiki: problemi, mozhlivosti, perspektivi» (16-17 lyutogo 2018 roku, m. Uzhgorod), Ministerstvo osviti i nauki Ukraïni Uzhgorodsykiy natsionalyniy universitet, 2018, s. 137-142, ISBN 978-966-916488-9. (Terziev, V., Banabakova, V., Georgiev, M. Social programming as a possibility to increase social efficiency. // Міжнародної науково-практичної конференції «Забезпечення сталого розвитку економіки: проблеми, можливості, перспективи» (16-17 лютого 2018 року, м. Ужгород), Міністерство освіти і науки України Ужгородський національний університет, 2018, с. 137-142, ISBN 978-966-916-488-9)

Terziev, Venelin. (2018u). The active model of a social programme and its strategic advantage. // ADVED 2018- 4th International Conference on Advances in Education and Social Sciences Abstracts \& Proceedings, 15-17 October 2018- Istanbul, Turkey, International Organization Center of Academic Research, www.ocerints.org, Istanbul, Turkey, 2018, pp. 189-203, ISBN: 978-605-82433-4-7.

Terziev, Venelin. (2018v). Active social programs development in Bulgaria: contemporary challenges and social management instruments. // ADVED 2018- 4th International Conference on Advances in Education and Social Sciences Abstracts \& Proceedings, 15-17 October 2018- Istanbul, Turkey, International Organization Center of Academic Research, www.ocerints.org, Istanbul, Turkey, 2018, pp. 149-163, ISBN: 978-605-82433-4-7.

Terziev, Venelin. (2018w). Social assistance services and integrated employment in Bulgaria. // ADVED 2018- 4th International Conference on Advances in Education and Social Sciences Abstracts \& Proceedings, 15-17 October 2018- Istanbul, Turkey, International Organization Center of Academic Research, www.ocerints.org, Istanbul, Turkey, 2018, pp. 164-177, ISBN: 978-605-82433-4-7.

Terziev, Venelin. (2018x). Impact of the labor market policies for ensuring employment. // ADVED 2018- 4th International Conference on Advances in Education and Social Sciences Abstracts \& Proceedings, 1517 October 2018- Istanbul, Turkey, International Organization Center of Academic Research, www.ocerints.org, Istanbul, Turkey, 2018, pp. 178-188, ISBN: 978-605-82433-4-7.

Terziev, Venelin. (2018y). Importance of human resources to social development. // ADVED 2018- 4th International Conference on Advances in Education and Social Sciences Abstracts \& Proceedings, 1517 October 2018- Istanbul, Turkey, International Organization Center of Academic Research, www.ocerints.org, Istanbul, Turkey, 2018, pp. 204-212, ISBN: 978-605-82433-4-7. 